\title{
FOTOGRAFIAS, CINEMAS, FANFARRAS E SÍTIOS ELETRÔNICOS. NOTAS SOBRE ACERVOS, PESQUISAS E COMPARTILHAMENTO EM RIO TINTO
}

\author{
CAIO NOBRE LISBOA ${ }^{1}$ \\ JOÃO MARTINHO BRAGA DE MENDONÇA ${ }^{2}$ \\ JOSÉ MUNIZ FALCÃO NETO ${ }^{3}$
}

\begin{abstract}
RESUMO
Esse texto procura abordar questões sobre acervos digitais a partir de pesquisas antropológicas com imagens fotográficas e fílmicas coletadas numa cidade do interior da Paraíba. 0 objetivo é discutir a abordagem etnográfica com a câmera e as imagens a partir de três movimentos. Primeiramente reflete-se de maneira geral sobre a formação de acervos visuais e audiovisuais concebidos em termos de fontes primárias. Num segundo momento, pesquisas com delimitações temáticas e metodologias mais específicas levam à formação de acervos audiovisuais associados a trabalhos de conclusão de curso. Por fim, são esboçadas algumas notas numa perspectiva das relações estabelecidas entre a universidade e a comunidade do entorno, na medida em que se discute a disponibilização das pesquisas e seus acervos em plataformas digitais. Procura-se, assim, explorar criticamente os múltiplos sentidos da ideia de "compartilhamento" para refletir sobre as possibilidades atuais de percepção e apropriação das pesquisas antropológicas via rede mundial de computadores.
\end{abstract}

\section{PALAVRAS-CHAVE}

Fotografia; Memória; Filme Etnográfico; Acervos; Antropologia Visual.

\section{PICTURES, CINEMAS, FANFARE BANDS AND SITES. NOTES ON ARCHIVES, RESEARCHES AND SHARING IN RIO TINTO}

\section{ABSTRACT}

This paper is focused on issues about anthropological research archives of pictures and movies in a small town of the state of Paraiba-Brazil. It has the aim to discuss ethnographic approach with camera and images in different steps. First, the general production and collecting of images as a primary source. Secondly, we present specific researches with their delimitations and methods that lead us to specific archives of work conclusions on graduation course. Finally, we try to point out some reflections on the relationships and collaboration between university and local communities, as we are concerned with the issue of the access or availability of these research products to local people by digital platforms (blogs, sites, etc.). So, we try to criticize the multiple meanings of the notion of sharing to reflect on the real possibilities of reception and appropriations of anthropological knowledge in the world wide web.

\section{KEY-WORDS}

Photography; Memory; Ethnographic film; Archives; Visual Anthropology.

\footnotetext{
${ }^{1}$ Mestrando do Programa de Pós Graduação em Antropologia (PPGA) da Universidade Federal da Paraíba (UFPB), Brasil.

${ }^{2}$ Professor Associado da UFPB/PPGA.

${ }^{3}$ Mestrando do PPGA/UFPB.
} 


\section{PHOTOS, CINÉMAS, FANFARE ET SITES. REMARQUES SUR LES ARCHIVES, LES RECHERCHES ET LEUR PARTAGEA RIO TINTO}

\section{RÉSUMÉ}

Cet article porte sur les collections digitales dans la recherche anthropologique avec des images photographiques et filmiques recueillies dans une ville de l'intérieur de Paraíba. L'objectif est de discuter de l'approche ethnographique avec la caméra et les images de trois façons. Premièrement, il se reflète généralement sur la formation de collections visuelles et audiovisuelles conçues en termes de sources primaires. Dans un second temps, des recherches avec des délimitations thématiques et des méthodologies plus spécifiques conduisent à la constitution de collections audiovisuelles associées à des travaux de conclusion de cours. Enfin, quelques notes sont présentées dans une perspective des relations établies entre l'université et la communauté environnante, en abordant la disponibilité de la recherche et de ses collections sur les plateformes digitales. Il s'agit d'explorer de manière critique les multiples significations de l'idée de "partage" pour réfléchir sur les possibilités actuelles de perception et d'appropriation de la recherche anthropologique via le World Wide Web.

\section{MOTS-CLÉS}

Images photographiques; Mémoire; Films ethnographiques; Archives; Anthropologie visuel

\section{FOTOS, CINES, BANDAS DE FANFARRIAS Y SITIOS ELECTRÓNICOS. COMENTARIOS SOBRE ARCHIVOS, INVESTIGACIONES Y COMPARTIR EN RIO TINTO}

\section{RESUMEN}

Este texto trata de abordar cuestiones sobre acervos digitales a partir de investigaciones antropológicas con imágenes fotográficas y fílmicas recogidas en una ciudad del interior de Paraíba. El objetivo es discutir el enfoque etnográfico con la cámara y las imágenes a partir de tres movimientos. Primero se refleja de manera general sobre la formación de acervos visuales y audiovisuales concebidos en términos de fuentes primarias. En un segundo momento, investigaciones con delimitaciones temáticas y metodologías más específicas conducen a la formación de acervos audiovisuales asociados a trabajos de conclusión de curso. Por último, se esbozan algunas notas en una perspectiva de las relaciones establecidas entre la universidad y la comunidad del entorno, en la medida en que se discute la disponibilidad de las investigaciones y sus acervos en plataformas digitales. Se busca, así, explorar críticamente los múltiples sentidos de la idea de "compartir" para reflexionar sobre las posibilidades actuales de percepción y apropiación de las investigaciones antropológicas a través de la red mundial de computadoras.

\section{Palabras Clave}

Imágenes fotográficas; Memoría; Películas etnográficas; Acervos; Antropología visual 


\section{INTRODUÇÃO}

O município de Rio Tinto localiza-se no Litoral Norte do Estado da Paraíba ${ }^{4}$ e abriga um novo Campus da Universidade Federal da Paraíba (UFPB), instalado a partir de 2006. O primeiro projeto de pesquisa que serve de base a esse artigo foi submetido em 2009 ao CNPq, para obtenção de apoio através de um edital específico (03/2009) para novos campi universitários ${ }^{5}$. Tal projeto propôs uma pesquisa exploratória em Antropologia Visual, a qual partiu do levantamento de fotografias antigas e de hábitos visuais (inclusive experiências com cinema, televisão e internet), com vistas à produção de conhecimentos que se utilizassem da imagem e do som, reelaborados com base em experiências etnográficas compartilhadas com moradores e moradoras da região.

Na época, alguns diálogos importantes, ao nível local e nacional, tiveram lugar durante o "Seminário Memória e Imagem no Vale do Mamanguape"6 (entre 6 e 9 de outubro de 2009), quando tivemos convidados locais, inclusive três fotógrafos comerciais há muito estabelecidos, líderes indígenas e um convidado vindo do Museu Nacional, Prof. José Sérgio Leite Lopes. Nesta ocasião ele apresentou e discutiu conosco seu filme, feito com Rosilene Alvim ${ }^{7}$ e Celso Brandão ${ }^{8}$, intitulado Tecido Memória ${ }^{9}$, sobre trabalhadores das Fábricas de Tecido do Município de Paulista - PE, um dos primeiros filmes doados ao acervo do que seria o futuro Laboratório de Antropologia Visual ARANDU (inaugurado em maio de 2011).

\footnotetext{
${ }^{4}$ O município de Rio Tinto foi desmembrado da atual cidade vizinha de Mamanguape - PB em 1956, quase quarenta anos depois de surgir como vila operária em função da instalação de uma fábrica de tecidos em terras de engenho de cana, ladeadas por áreas de ocupação indígena (Potiguara). Segundo o IBGE, atualmente conta com uma população estimada de 24.090 mil habitantes. Disponivel em: $\leq$ http://cidades.ibge.gov.br/xtras/perfil.php?codmun=251290>. Acesso em: julho de 2017.

${ }^{5}$ Sob orientação do prof. João Martinho de Mendonça, diversos estudantes trabalharam no projeto "Município de Rio Tinto e T.I. Potiguara: explorações iniciais de antropologia visual" como parte de sua iniciação científica, alguns defenderam também Trabalhos de Conclusão de Curso (ou TCCs): Antonio Pedro Soares, Danilo Alex Marques de Farias, Luana Maia Pinto, Caio Nobre Lisboa e José Muniz Falcão Neto. Os dois últimos desenvolvem atualmente suas pesquisas em nível de Mestrado na UFPB, o que nos levou à elaboração desse artigo (em colaboração efetiva) para a chamada da Revista Mundaú.

${ }^{6}$ Iniciativa do curso de graduação em antropologia da UFPB/Rio Tinto, que teve sua primeira turma em 2007.

${ }^{7}$ Professora e pesquisadora do UFRJ/Museu Nacional.

${ }^{8}$ Fotógrafo e pesquisador pelo Museu Théo Brandão em Maceió-AL.

${ }^{9}$ Filme documentário premiado em 2010 pela Associação Brasileira de Antropologia. Para mais informações consultar: <www.abant.org.br>. Acesso em: julho de 2017.
} 
Esse primeiro contato com fotógrafos locais e ex-trabalhadores da fábrica de tecidos $^{10}$ nos levaria, posteriormente, à Fundação Cultural da cidade onde ficavam guardados cinco painéis com cento e cinquenta e três fotografias, expostas na ocasião do cinquentenário da cidade em 2006. Foi possível encontrar algumas destas mesmas imagens também disponíveis num sítio eletrônico ${ }^{11}$. As indicações dos fotógrafos e das próprias fotografias conduziram, por sua vez, à outras tantas imagens. Desse contexto inicial de formação de acervo para pesquisas surgiriam, nos anos seguintes, dois trabalhos de conclusão de curso $^{12}$, a saber, sobre a performance de músicos em fanfarras do desfile cívico anual e sobre o funcionamento e impacto sócio-cultural do cinema na região, já integrados em outro projeto contemplado pelo Edital CNPq 43/2013 ${ }^{13}$.

As trajetórias etnográficas seguidas em Rio Tinto e na cidade vizinha de Mamanguape fornecem, portanto, a base das reflexões propostas aqui. As relações dos pesquisadores com os diferentes sujeitos encontrados durante a pesquisa são objeto de uma reflexão incontornável acerca do que representa a instalação de um campus universitário numa cidade do interior. Se admitimos, enfim, que o fundamento do conhecimento a ser produzido é dialógico, como equacionar as formas de relação intersubjetiva postas em prática na pesquisa e seu papel no âmbito de uma reflexão ética mais ampla? E como pensar estas relações sob o atual ambiente comunicacional proporcionado pela rede mundial de computadores com seus múltiplos aplicativos e sítios eletrônicos?

\section{AS IMAGENS, SUA PASSAGEM E PERMANÊNCIA EM REDES}

Com base em experiências anteriores conhecidas (SIMSON, 2007; ECKERT; ROCHA, 2004) acerca da dificuldade na obtenção de autorizações escritas assinadas para publicação de material fotográfico de pesquisas, uma estratégia específica de abordagem se fazia necessária. A partir, também, da centralidade da imagem como fonte primária da pesquisa, o desenvolvimento de um período de inserção junto aos moradores foi inicialmente

\footnotetext{
${ }^{10}$ A fábrica de tecidos foi inaugurada em 1924, posteriormente tornou-se a "Companhia de Tecidos Rio Tinto", fornecedora das conhecidas "Lojas Pernambucanas", espalhadas em várias cidades brasileiras.

11 Disponíveis em: <http://www.riotintopb.com.br/f5read/galeria/galeria.php?varimg=151>. Acesso em: novembro 2010. Esta exposição foi produzida pelo Dr. Antonio Luiz (colecionador local) e pelo fotógrafo Hildebrando Domingos. Usaremos os termos "sítio eletrônico" (sites), "páginas eletrônicas" (páginas de aplicativos tais como facebook) ou "canais eletrônicos" (p. ex. youtube).

${ }^{12}$ Respectivamente por Caio Nobre Lisboa e José Muniz Falcão Neto, autores aqui em colaboração com seu orientador João Martinho de Mendonça.

${ }^{13}$ Acervos e Antropologia Visual: diálogo e conhecimento das imagens na região de Rio Tinto - PB (CNPq 43/2013), coordenado por João Martinho de Mendonça.
} 
experimentado na relação direta com fotógrafos locais, posteriormente desdobradas para seus clientes e/ou amigos.

Foi assim que um dos fotógrafos da cidade aceitou colaborar conosco distribuindo aos seus clientes e amigos uma espécie de ficha, contendo um resumo das intenções do projeto $^{14}$, a ser preenchida por quem visitasse sua loja e tivesse interesse. Esse preenchimento identificava o nome, endereço e telefone do colaborador e a maneira como pretendia colaborar, seja mostrando fotografias guardadas, identificando pessoas ou acontecimentos em fotografias ou contando histórias sobre fotógrafos mais antigos. O uso da ficha implicava, portanto, em que os potenciais colaboradores lessem e escrevessem seu nome e endereço no papel.

Como instrumento de pesquisa, esse expediente foi concebido para atrair clientes e/ou amigos dos fotógrafos. Pessoas que, eventualmente, se interessassem pela fotografia e pelas "histórias" da cidade ${ }^{15}$. Tal procedimento foi experimentado num primeiro momento, mas não com exclusividade. Outros tipos de abordagens, em sua maioria presenciais, também se fizeram importantes, senão fundamentais. A noção de redes, muito discutida na antropologia ${ }^{16}$, significava um desafio tanto mais quanto pensávamos em suas conotações teóricas, presenciais e virtuais.

Além do mais, tínhamos como suposição básica o fato de que as fotografias mais antigas e mesmo sua conservação estavam ligadas a um tipo de clivagem social: assim como a escrita, a fotografia foi difundida inicialmente entre uma parcela específica da sociedade, cujo excedente econômico thes permitia contratar os serviços (a custos altos) de fotógrafos. O mesmo excedente econômico também justificava o uso da fotografia como marca de distinção social. Mas o que diversos autores demonstraram em termos da associação entre fotografia e ascensão sócio-econômica burguesa no século XIX, não deixa de fazer ver também outra associação importante: fotografia e urbanização.

Fotografias antigas guardadas, portanto, carregam potencialmente o testemunho de trajetórias de famílias inteiras, quando não de cidades mesmo. Mas como elas poderiam revelar, também, as trajetórias de líderes e/ou personalidades oriundas de outros tantos diferentes segmentos sociais, inclusive em áreas indígenas e zonas rurais? A pesquisa fotográfica concebida a partir dos métodos da antropologia visual, de toda maneira, nos fez perceber diferentes aspectos ligados à circulação e veiculação de fotografias antigas, entre

14 Basicamente a formação de um acervo de imagens fotográficas da cidade de Rio Tinto acompanhadas de outras informações sobre histórias de vida, acontecimentos importantes etc., incluindo aí a história dos fotógrafos da cidade.

${ }^{15}$ Buscamos, portanto, perceber uma parte das redes de relações destes fotógrafos.

${ }^{16}$ Ver o número especial dedicado à noção de redes na Revista lluminuras e nosso artigo lá publicado (MENDONÇA, 2011). 
os âmbitos privado e público. Ajudou a conhecer e revelar, assim, principalmente pelas coleções particulares, diversas cenas de acontecimentos significativos em termos da história e dos costumes da região.

Mas será que estas fotografias antigas da cidade comportam um valor que constitui objeto de disputas simbólicas? Até que ponto aquilo (em termos de instituições: Escolas, Prefeitura, Universidade) que pode ser identificado com uma "tradição escrita" tende a reivindicar para si o direito de apropriação destas imagens no âmbito de suas próprias estratégias discursivas? De que maneira essa tendência pode ser percebida pelos sujeitos ao nível de uma microética, nas relações face a face ${ }^{17}$ Ou seja, as narrativas associadas a estas imagens podem adquirir os mais variados contornos e direções dependendo das pessoas abordadas e das perspectivas a partir das quais são visualizadas.

O acervo reunido durante nossas pesquisas constituiu uma base, todavia, que serve efetivamente para novas pesquisas bem como para produções culturais. Mas como conceber sua disponibilização para pesquisadores ou para consultas junto à população local? Bastaria simplesmente fazer o upload das imagens para quaisquer plataformas digitais ou aplicativos simuladores de redes sociais? A manutenção destas imagens no acervo e as possibilidades de sua circulação não deveriam, até pelo que propôs nossa pesquisa, estar condicionada à manutenção das relações interpessoais estabelecidas com os sujeitos cedentes das (ou implicados pelas) imagens? Em outras palavras, propõe-se que a manutenção e os usos do acervo imagético contribuam diretamente no estreitamento dos laços estabelecidos entre a universidade e a vida das pessoas.

Nesse sentido, os resultados da pesquisa fotográfica e antropológica podem ser compartilhados, continuamente, através de realizações visuais (vídeos, exposições etc.) destinadas, por exemplo, às escolas e aos espaços culturais do município ${ }^{18}$. O vídeo Passagem e Permanência ${ }^{19}$ foi, sem dúvida, um primeiro movimento nessa direção. Estas reflexões sobre possibilidades de construção de relações éticas no levantamento e tratamento das imagens reunidas e/ou produzidas na pesquisa antropológica, constituem

\footnotetext{
${ }^{17}$ Entre familiares, vizinhos e conhecidos. Outras reflexões que nos serviram também de premissas encontram-se no artigo "Ética, oralidade e pesquisa fotográfica” (MENDONÇA, 2012).

${ }^{18}$ Atualmente um projeto educacional da prefeitura de Rio Tinto deverá incluir os vídeos realizados pelo nosso grupo de pesquisa AVAEDOC/UFPB/CNPq num circuito de sessões destinadas às escolas locais, onde uma espécie de espaço cultural está em implementação (no chamado "Palacete" ou "Casarão", hoje pertencente à área indígena de Jaraguá, vizinha ao Campus IV da UFPB em Rio Tinto).
}

19 "Passagem e permanência: três ensaios em torno do sete de setembro em Rio Tinto - PB", 18 min, 2012. Produzido em DVD para distribuição nas escolas locais. Disponível em: s https://vimeo.com/62924767>. Acesso em: julho de. 2017. 
desafios complexos. Vejamos como foram enfrentados nas duas experiências relatadas a seguir.

\section{NA TRILHA DAS FANFARRAS: ETNOBIOGRAFIA, PESQUISA FÍLMICA E ELICITAÇÃO POR IMAGENS}

No início da noite de 08 de maio de 2014 fomos apresentados ${ }^{20}$ ao Agnaldo da Silva Mendes. Músico concursado ${ }^{21}$ da Banda de Música Municipal Antônio Cruz e instrutor de longa data da Fanfarra Antônia Luna Lisboa, da Banda Marcial da Escola Severina Coutinho, da Banda Marcial do Serviço de Convivência e Fortalecimento de Vínculos (antigos PET e PROJOVEM) de Mataraca - PB, também contratado pela Banda de Música de Mamanguape.

Tratava-se de um plano de pesquisa denominado Memórias e imagens de bandas de música em Rio Tinto (Edital interno PIVIC 2013-2014), que tinha, dentre outros objetivos, a proposta de aprofundar o estudo das imagens de acervos de diferentes procedências (particulares e públicos) então reunidos no Laboratório de Antropologia Visual Arandu (a partir dos projetos já mencionados na seção anterior), com atenção maior para as memórias das bandas de música de Rio Tinto.

Desde esse primeiro encontro, em sua casa, Agnaldo da Silva Mendes, ou como chamaremos de agora em diante, Seu Agnaldo, logo demonstrou interesse em colaborar conosco. Pouco mais de um mês depois, já tínhamos realizado duas sessões de "vídeoelicitação" (BANKS, 2009) com o filme Passagem e permanência, o qual aborda as memórias dos desfiles cívicos em Rio Tinto, quando também iniciávamos os registros para a "história de vida" (QUEIROZ, 1988) de Seu Agnaldo.

Seu Agnaldo via com simpatia a possibilidade de registrar audiovisualmente a Fanfarra Antônia Luna Lisboa e a Banda de Música Antônio Cruz, com as quais ele tem uma relação muito íntima desde a juventude, já que trabalhou nelas desde seus momentos iniciais de formação. No ano seguinte, já a partir de um segundo plano anual de pesquisa, intitulado Ver e ouvir: memórias de músicos em Rio Tinto (Edital interno PIBIC, 2014-2015) o Trabalho de Conclusão do Curso de Antropologia começou a ganhar seus contornos finais.

Junto às metodologias de elicitação por imagens e de história de vida já mencionadas, passamos a incorporar as reflexões sobre "etnobiografia", "[...] produto e constructo de uma relação que altera percepções no processo mesmo de sua criação"

\footnotetext{
${ }^{20}$ Por Eduardo Potiguara, um amigo e colega da Graduação em Antropologia.

${ }^{21}$ Saxofonista-alto dessa cena musical de bandas marciais, fanfarras e bandas de música de Rio Tinto.
} 
(GONÇALVES, 2012, p. 29) 22, bem como a metodologia da "antropologia fílmica" (FRANCE, 1998). Assim, juntamente com o TCC defendido em 2016, Ofício e performance do músico no desfile cívico de sete de setembro em Rio Tinto: aproximações antropológicas (2016), apresentamos o vídeo $A$ música e as bandas no contexto do desfile cívico de Rio Tinto - PB $(2016,12: 59)^{23}$.

A respeito da memória, utilizamos a conceituação de Michael Pollak (1989; 1992) segundo a qual as memórias constituem um fenômeno individual e socialmente construído. Por elas se expressa o sentimento de pertencimento e identidade nas pessoas, sendo então imagens formadas para si e para outrem, que resultam em conformações de continuidade, coerência e fronteiras entre o "nós" e o "outro" (POLLAK, 1992, p. 204).

São formadas, pois, de acontecimentos, personagens e lugares experienciados durante trajetórias de vida individuais ou coletivas, direta ou indiretamente (quer dizer, por informações que se aprende de seu próprio grupo). Seja no próprio tempo-espaço de vivência (as experiências vividas efetivamente por uma pessoa), ou em outro, apenas sentido por projeções, em outras palavras, pela transmissão oral ou escrita que uma geração faz para outra (POLLAK, 1992, p. 201-203).

\section{O OUVIDO COMO “PONTO DE VISTA" DO MÚSICO}

A experiência de elicitação com Seu Agnaldo, porém, superou em muito nossas expectativas. A partir de seu afinado ouvido de músico, ele identificou com notável precisão elementos da montagem da banda sonora ${ }^{24}$ no filme Passagem e Permanência. A saber, a não sincronização completa entre imagens e sons durante as cenas montadas a partir das performances tomadas no desfile Sete de Setembro em 201125. Ele pôde, portanto, identificar a continuidade das cadências e músicas da fanfarra Antônia Luna Lisboa, mesmo quando as imagens apresentavam performances de outras fanfarras.

22 Inspirado por Walter Benjamim, Gonçalves escreve que a "[...] etnobiografia depende da capacidade de 'intercambiar experiências', no sentido de potencializar a experiência mesma da narração partilhada pelo instante etnográfico" (BENJAMIN, 1987, p. 198 apud GONÇALVES, 2012, p. 21).

${ }^{23}$ Disponível em: $\leq$ https://youtu.be/so0sIzFpK2A>. Acesso em: julho. 2017.

24 "banda sonora" aqui se refere à representação da trilha sonora do filme, que é visualizada pelas interfaces dos aplicativos de edição de vídeo não linear (digital).

${ }^{25}$ Referimo-nos particularmente ao segundo ensaio desse vídeo: Como conhecer o que apenas está de passagem? - Onde nossa câmera filmadora se aproxima dos gestos e sons do desfile. 
Ele também identificou outras bandas em que tocava na época, bem como aquelas nas quais não tomava parte ${ }^{26}$, mencionando os instrutores que pertenciam a estas, outras pessoas conhecidas e as mudanças percebidas por ele entre o ano de produção do filme (2011) e o ano em que as elicitações em questão estavam sendo realizadas (2014). Lembrouse ainda de situações em família, dos primeiros desfiles que participou, e da relação com os fotógrafos tanto nos desfiles como em outras situações cotidianas.

Por essa razão resolvemos chamar essas experiências de áudio-vídeo-elicitações, a fim de destacar a atenção particular dada ao "ouvir" sons musicais ${ }^{27}$. Assim, "ouvir" enquanto operação de cognição nos pareceu tão importante quanto o "olhar" 28 , igualmente evocador de memórias e sentimentos (HALBWACHS, 1990) tanto quanto as fotografias e o vídeo. Seu Agnaldo, dessa maneira, nos motivou a continuar, no ano seguinte, com o mesmo caminho que vínhamos esboçando, com base também na noção de "etnobiografia": o exercício de uma "antropologia compartilhada".

Ele seria, além de personagem principal, um tipo de diretor de filmagem, por solicitação nossa. Foi um exercício de compartilhar com ele a própria posição da câmera dependendo da situação ${ }^{29}$, bem como a decisão sobre quais pessoas deveríamos filmar. Assim que nesse gesto de compartilhar colocávamos em questão a noção de "[...] filmagem etnográfica purista" (PRELORÁN, 1987, p. 13), uma vez que já não se tratava de tentar reconstruir, dramatizar, ficcionalizar ou representar situações, a partir de um único "(...) ponto de vista de um observador, na terceira pessoa - com câmera 'invisível', e a ação diante dela espontânea e desinibida" (PRELORÁN, 1987, p. 14).

No desfile de Sete de Setembro de 2015 efetivamente nos utilizamos da antropologia filmica de Claudine de France (1998), restituindo os tempos fracos (a diminuição de ritmo da atividade principal ou repetições) e os tempos mortos (a cessação da atividade principal) às gravações (FRANCE, 1998, p. 81-82), o que tornaram os registros mais longos. Dessa maneira, registramos imagens que, por sua vez, traziam um diálogo mais próximo com os integrantes da Fanfarra, com alguns longos planos sequência.

\footnotetext{
${ }^{26}$ A cena musical de bandas marciais, fanfarras e bandas de música de Rio Tinto se reorganiza todos os anos dentre julho e setembro, logo que finaliza o período das quadrilhas juninas, culminando nos desfiles cívico-militares da semana da pátria e em encontros de bandas realizados em outras cidades próximas após o sete de setembro.

${ }^{27}$ No sentido amplo de R. Murray Schafer, que alavanca todos os sons do mundo como pertencentes "[...] a um campo contínuo de possibilidades, situado dentro do domínio abrangente da música" (SCHAFER, 1991, p. 121).
}

\footnotetext{
${ }^{28}$ Ver sobre isto a entrevista realizada com Roberto Cardoso de Oliveira sobre seu artigo onde questiona os atos de "olhar, ouvir e escrever" no trabalho antropológico (SAMAIN; MENDONÇA, 2000).

${ }^{29}$ Não registramos ensaios da Banda de Música Antônio Cruz, só de suas apresentações nos desfiles de 2014 e 2015.
} 


\section{ACERVO DA PESQUISA SOBRE MÚSICOS DAS FANFARRAS: DESAFIOS DA RESTITUIÇÃO}

Passados dois anos, coletamos um material com gravações em vídeo de duração total de 5 hs 36 min e 30 seg, gravações de áudio com duração total de 03 horas, 53 minutos e 19 segundos e fotografias no total de 599 fotos. Sendo que o tratamento que recebeu cada um desses materiais foi um tanto diferente. Ora, se com os vídeos e os áudios fomos mais cuidadosos com a sua publicação nas redes sociais, inclusive por uma demanda de Seu Agnaldo, o mesmo não se deu com as fotografias ${ }^{30}$, realizadas justamente com o propósito de restituição mais imediata pelas redes sociais.

Mesmo após montado o vídeo, esperamos um período de um ano ainda para que estivessem plenamente resolvidas questões como edição final e sua devida regulamentação, no sentido de assinatura de termo de concessão de imagens de Seu Agnaldo, garantindo-lhe os propósitos estritamente acadêmicos da pesquisa. Elaboramos então um DVD com uma arte de capa e de disco, e entregamos a Seu Agnaldo, cópias para ele e seus irmãos, junto a uma cópia da versão final do trabalho escrito. O mesmo foi feito para a Escola Antônia Luna Lisboa e para a Banda de Música Antônio Cruz.

Foi nesse contexto que o vídeo A música e as bandas no contexto do desfile cívico de Rio Tinto - PB foi exibido - com a permissão de Seu Agnaldo - na Mostra Arandu de Filme Etnográfico de 2016, na 30ª Reunião Brasileira de Antropologia, em João Pessoa, sendo também recentemente aceito para a Mostra de Filmes do $41^{\circ}$ Encontro Anual da ANPOCS (2017), em Caxambú - MG. Foi também submetido ao $8^{\circ}$ Festival Internacional do Filme Etnográfico do Recife - PE (2017), estando assim circunscrito ao âmbito de mostras universitárias e festivais etnográficos ${ }^{31}$. Ao mesmo tempo, mais diálogos e revelações emergem agora numa pesquisa de Mestrado.

\section{O CINEMA COMO MEMÓRIA COLETIVA DO VALE DO MAMANGUAPE}

Os apontamentos seguintes, sobre a formação de outro acervo ${ }^{32}$ associado às memórias do cinema, são oriundos do Trabalho de Conclusão de Curso de José Muniz Falcão

\footnotetext{
${ }^{30}$ Produzidas em colaboração com outro colega da graduação, Geraldo de França Alves Júnior.

31 O conjunto desse trabalho teve também a honra de receber o segundo lugar do Prêmio LéviStrauss, modalidade Pôster, concedido pela ABA, na RBA de 2016.

32 Temos utilizado a expressão "acervos de pesquisa" para denotar o conjunto de materiais (audiovisuais, escritos e sonoros) reunidos ao longo de nossas pesquisas, às vezes referidos mais especificamente a um TCC ou Dissertação. Esse sentido é também aproximado à noção de "coleções etnográficas", articulada ao trabalho com "memórias coletivas", há muito desenvolvido no BIEV/UFRGS sob coordenação das profas. Cornélia Eckert e Ana Luíza Carvalho de Rocha (ECKERT; ROCHA, 2015).
} 
Neto $^{33}$. Foi também desenvolvido com base em participações em Programas Institucionais de Bolsas de Iniciação Científica (PIBIC/PIVIC), integrado ao projeto maior já mencionado na seção anterior (contemplado pelo Edital CNPq 43/2013 para Ciências Humanas) e finalmente intitulado: Cinema no Vale do Mamanguape: aproximações antropológicas.

Ao longo desse percurso, durante pelo menos dois anos buscamos por histórias que relatassem a época dos antigos cinemas da região, pois apesar dos anos que se passaram, permanecia viva no imaginário local e bem rememorada essa época de "ouro" do cinema no vale. Nosso interesse era elaborar as memórias coletivas relacionadas ao cinema no vale do Mamanguape - PB. Mais especificamente, em relação aos dois cinemas da região, o Cine Teatro Eldorado (1965) e o Cine Teatro Orion (1943), respectivamente localizados nas cidades de Mamanguape e Rio Tinto.

Partindo de procedimentos metodológicos inspirados no "cinema direto" 34 e na "antropologia compartilhada"35, foram feitas diversas filmagens, compondo um acervo audiovisual $^{36}$ que apresenta diversos personagens, os quais relatam suas experiências e vivências dentro das salas de cinema na região. Antes de abordar o vídeo produzido a partir desse acervo, parte integrante do TCC referido acima, esperamos esclarecer um pouco da trajetória de pesquisa que levou às imagens então reunidas. Experiência etnográfica a um só tempo presencial e virtual, da qual emergem várias questões éticas no que diz respeito ao compartilhamento destas memórias coletivas.

\section{Fotografias antigas em sítios eletrônicos}

No decorrer da pesquisa a coleta de fotografias foi um dos problemas enfrentados. Nosso principal interlocutor, o "Júnior da Locadora"37 foi bastante restrito em termos do empréstimo de fotografias de sua coleção particular. Naquela altura já conservava uma série de fotografias antigas a respeito dos cinemas, sejam oriundas de sua própria família ou

\footnotetext{
${ }^{33}$ Sob orientação de João Martinho de Mendonça (PPGA/AVAEDOC/UFPB).

${ }^{34}$ Termo utilizado nos EUA para referir um estilo de cinema desenvolvido nos anos 1960, com câmeras mais leves e fora de estúdios.

${ }^{35}$ Termo utilizado pelo antropólogo e cineasta Jean Rouch para elaborar a especificidade de seu estilo de cinema direto antropológico, em consonância com as discussões feitas na época, mais específicamente na França, em torno da expressão "cinema verdade".

36 Total de filmagens: 7h:59min:7s.Total de fotografias: 188. Total de áudios (registro oral): $115 \mathrm{~min}: 73 \mathrm{~s}$.

${ }^{37}$ Walfredo David Júnior, filho de Walfredo David e sobrinho de Abel David, ambos administradores dos antigos cinemas Cine Teatro Eldorado (a partir de 1965) e Cine Teatro Orion (a partir de 1964). Júnior ganhou este apelido de seus muito frequentadores, quando abriu uma locadora de filmes em VHS.
} 
coletadas com outros moradores. Em posse dessa coleção, que julgamos preciosa, ele mesmo as digitalizou e criou uma página num aplicativo de internet, a qual nomeou de "Mamanguape conta suas histórias" 38 .

Num dos encontros que tivemos no Centro Cultural Fênix ${ }^{39}$, fizemos a pergunta de como ele tinha conseguido aquelas fotografias, se eram todas dele ou se alguém tinha the dado. Ele respondeu que um dia pensou em fazer uma página eletrônica para divulgar as histórias da cidade, coisa que ele já fazia há mais tempo, quando ia até a rádio local Litoral Norte (a convite) relatar um pouco da história dos cinemas no Vale. Vinha daí, portanto, sua motivação para a coleta de fotografias com outros moradores. Com a internet, portanto, ele poderia digitalizar e deixar mais acessíveis essas imagens e suas histórias.

Ficava nítido, assim, seu desejo de ser reconhecido como o principal guardião da memória dos cinemas, já que foi a atividade mais notável exercida por sua família na região do Vale do Mamanguape. Suas fotografias colecionadas são para ele "bastante pessoais" e the "causam emoções". Quando the pedíamos para ver as fotos, ele respondia simplesmente: "vai lá na página que tem, tem lá, postei tudinho lá". Uma possível digitalização das mesmas no Laboratório de Antropologia Visual Arandu, seguida de restituição imediata ao seu detentor ${ }^{40}$, tornou-se impossível no tempo em que tivemos para concluir nossa pesquisa.

Assim, a maior parte do acervo das fotografias reunidas nesta pesquisa, sobre os cinemas, foi obtida através de sua página eletrônica (por download, depois impressas ampliadas em tamanho A4). Numa entrevista com a câmera no tripé, trabalhei com a "fotoelicitação" (BANKS, 2009) e não foram poucos os momentos em que ele expressou seu sentimento pessoal por aquelas fotos. Em muitas delas ele colocou até uma pequena marca d'agua em referência à sua página eletrônica. Essa dificuldade nos levou a novas descobertas e desafios, teríamos que adentrar as discussões metodológicas relativas ao que tem sido chamado de "netnografia" ou "etnografia virtual"?

Ao menos alguma reflexão mínima se fazia imprescindível, já que a interação "real" no cotidiano engloba também, de certo modo, interações virtuais, permitindo a comunicação de várias distâncias e de distintos modos. Na atual sociedade da informação as imagens são muitas vezes o alvo comunicacional, constituem modos de interação, sendo ativas na composição grupos e sentimentos comuns. Рara Silva (2005, p. 208), "[...] o virtual não é o oposto do real, mas sim uma esfera singular da própria realidade, onde as categorias de espaço e tempo estão submetidos a um regime diferenciado."

38 Disponível em: <https://www.facebook.com/mamanguapecontasuashistorias/?fref=ts>. Acesso em: julho de. 2017.

39 Instituição localizada no Centro de Mamanguape, com espaços para exposições e uma sala de exibição de vídeo que funciona como cineclube, sob a direção de Júnior.

${ }^{40}$ Procedimento adotado em diversos outras situações de pesquisa com moradores locais. 
Foi então que a página eletrônica de Júnior e sua comunidade virtual (ou sua rede social) se tornou, também, nosso campo de pesquisa. As fotos postadas de sua coleção trazem consigo legendas de vários tipos, desde referências a quem pertencia uma ou outra fotografia ${ }^{41}$ até pequenas histórias a respeito do contexto da cena fotografada. Como por exemplo o ano, o que tinha acontecido no dia, os personagens que ali estavam e algumas outras descrições. Noutros casos ele realiza pequenas foto-montagens ${ }^{42}$, com duas ou três fotografias, cujos elementos são esclarecidos e articulados pelas legendas.

A análise dessas fotografias nos sítios eletrônicos, juntamente com suas legendas e comentários de terceiros ${ }^{43}$, foram de extrema importância para localizar outras pessoas, potenciais colaboradoras em nossas pesquisas. Ajudaram efetivamente a entender com mais nitidez o poder do cinema naquela época, quando as fotografias antigas faziam lembrar e comentar os "tempos de ouro" 44 dos cinemas na região, evocando dessa maneira toda uma memória coletiva em plena duração.

O mundo "virtual" se tornou, assim, uma espécie de extensão da "realidade". Nesse universo virtual ${ }^{45}$ as pessoas se expressavam e comunicavam, de maneira a interligar o momento presente ao passado vivido, em comentários provocados pelas fotografias. Tais comentários livres muitas vezes levaram a repensar o lugar do outro nestas experiências etnográficas mediadas por computadores. Por exemplo, "[...] poder-se-à imaginar um mundo virtual mais real do que o mundo real, em que cada um representa o personagem que desejaria ser, pelo menos nesse momento, na sua vida real [...]" (SILVA; JUSTIÇA, 2005, p. 224)?

Foram reunidas, ao longo do tempo de pesquisa, setenta e duas fotografias antigas de sua página eletrônica ${ }^{46}$, as quais mostram assuntos diversos, não só do cinema, mas também de outros lugares de Mamanguape e Rio Tinto. As fotos foram sendo "baixadas" na medida em que ele ia postando. Com sua autorização e publicização destas imagens fotográficas antigas, ficamos à vontade para guardá-las e utilizá-las na pesquisa etnográfica.

\footnotetext{
${ }^{41}$ Alguns desses acervos eram os Acervos Gilberto Nogueira e Acervo José Lins do Rêgo.

42 Ver por exemplo uma dessas foto-montagens em sua página eletrônica. Disponível em: <https://www.facebook.com/mamanguapecontasuashistorias/?fref=ts $>$. Acesso em: outubro de 2015.

${ }^{43}$ Comentários feitos nas postagens das fotografias.

44 Termo usado frequentemente pelos moradores antigos das cidades de Rio tinto-PB e Mamanguape-PB, para expressarem os bons tempos de quando os cinemas eram ativos.

${ }^{45}$ Também conceituado em termos de "cibercultura", ver por exemplo: (SEGATA; RIFIOTIS, 2016).

${ }^{46}$ As quais incorporamos ao acervo de nossas pesquisas em arquivos de formato JPG, com a devida referência da fonte em seu sítio eletrônico.
} 
Algumas destas fotografias serviram, também, para elaborar a introdução do filme apresentado juntamente com o TCC $^{47}$.

\section{O USO DA CÂMERA NA PESQUISA: INSTRUMENTO DE DIÁLOGO}

Depois dos contatos e gravações iniciais com Júnior e com outro importante colaborador, o Sr. Naldo, antigo fotógrafo da cidade, além de nossas incursões de pesquisa nos sítios eletrônicos, duas constatações se fizeram presentes. Primeiro, que as memórias coletivas do cinema na região iam ainda muito além daquilo que nosso principal colaborador nos relatava, já que tanto em conversas presenciais quanto nos sítios eletrônicos o assunto entusiasmava muita gente. Percebemos então que era o momento de ir ao encontro presencial dessas pessoas para efetuar novas gravações, usando a câmera como nosso instrumento de diálogo e criação.

Buscamos, para isso, inspiração nas estratégias do cinema direto, ou seja, usar a câmera fora de estúdios, como comunicação com a realidade para capturar as relações, interações e diálogos entre personagens (MARIE, 2012; SILVA, 2012) e destes com o pesquisador. Foi assim que procuramos exercitar modalidades de "antropologia compartilhada":

A perspectiva que vai se construindo não é a de uma câmera de filmar que registra dados etnográficos, mas a de instrumento de comunicação com a realidade etnográfica. Esse é o primeiro elemento complexificador introduzido por Jean Rouch [...] (BARBOSA; CUNHA, 2006, p. 36).

Desse modo, pensávamos em como desenvolver estratégias de abordagem com a câmera рага que ficasse bem clara a dimensão ampla que o cinema representou na vida das pessoas. Segundo Canevacci (1990), o cinema foi um fenômeno que conseguiu colocar em um só espaço pessoas das mais diferentes características e classes, num verdadeiro ritual coletivo. Em qualquer lugar onde fôssemos, de fato, sempre encontrávamos diversas pessoas que já tinham ido a algum dos antigos cinemas, as quais tinham várias histórias a contar.

Duas frentes de abordagem foram então concebidas: aquela que seguia o próprio movimento do cineclube organizado pelo Júnior ${ }^{48}$, com ênfase nos seus frequentadores, bem como um percurso direto pelas ruas e praças contíguas aos locais dos velhos cinemas, como por exemplo: a Praça Treze de Maio, em Mamanguape; e a Praça João Pessoa, em Rio Tinto. Dessa última frente surgiu uma das personagens mais notáveis de nosso filme, uma antiga frequentadora do Cine Orion em Rio Tinto.

\footnotetext{
${ }^{47}$ Disponível em: <https://vimeo.com/225632493>. Acesso em: julho de 2017.

${ }^{48}$ De algum modo, a retomada do movimento de cineclube em Mamanguape pelo Júnior coincidia e se nutria, também, do diálogo que tínhamos iniciado, na medida em que organizávamos, junto com outros estudantes, em 2014, o cineclube Vertov, nas dependências do laboratório ARANDU/UFPB.
} 
Sempre que saíamos com a câmera tínhamos a preocupação sobre como seria a abordagem e como poderíamos utilizar aquelas imagens realizadas, sem que se comprometesse a ética profissional e o respeito à imagem do "outro" ${ }^{49}$. Na maioria das vezes, ângulos e enquadramentos foram indicados pelas pessoas filmadas, esta postura foi adotada para deixá-los cientes de que o trabalho se dava de maneira colaborativa tanto quanto consentida, de modo a exercitar a confiança e a continuidade das relações estabelecidas.

Após as filmagens, mostrávamos as imagens às pessoas filmadas e esclarecíamos nossa intenção em trabalhar com elas na universidade, deixando-as o mais à vontade possível. Procuramos, assim, manter um trabalho de diálogo que possibilitasse a quebra hierárquica entre o "eu" pesquisador e o "outro" sujeito, num trabalho concebido e exercitado de maneira coletiva e compartilhada (NOVAES, 2009). A câmera, portanto, serviu também como instrumento de comunicação que aproximou relações e possibilitou o diálogo constante com aqueles que contavam as histórias sobre o cinema na região ${ }^{50}$.

Por fim, uma notável oportunidade de filmagem aconteceu num dos eventos organizados pelo Júnior ${ }^{51}$, no antigo prédio do Cine Teatro Orion, intitulado Cine Saudade. Nesta ocasião foram exibidos filmes antigos, tais como: Dio comi te amo, Django, Mazaroppijecão Um fofoqueiro no céu, O Exorcista, Teixeirinha Coração de luto e Charles Chaplin Tempos Modernos. O evento foi promovido no período de 30 de abril a 06 de maio de 2016. Segundo Júnior, a finalidade do evento era rememorar e dar aos antigos moradores a oportunidade de reviver os antigos tempos do Cine Orion. Havia ainda uma pequena exposição de fotografias antigas sendo expostas ao público, que faziam e fazem parte de sua coleção, nas quais ele também referia sua página eletrônica Mamanguape conta suas histórias.

Esse evento marcou também o encerramento de nosso período de filmagens para a pesquisa. Os planos adotados nessa ocasião foram em sua maioria planos longos, abertos e médios, com zoom nas imagens dos filmes, a fim de captura-los e relacioná-los com os discursos dos personagens filmados. Também foram feitas tentativas de travelling, começando de um close na imagem do filme, e abrindo (plano geral) para mostrar a sala de cinema e o público presente ${ }^{52}$. Nas situações com baixa luminosidade, aproveitamos o som e

49 Sempre antes de iniciar a captura de imagens, perguntávamos às pessoas sobre seu consentimento para filmá-las.

50 Tal como podemos observar no vídeo, disponível em: <https://vimeo.com/225632493>. Acesso em: julho de 2017.

\footnotetext{
${ }^{51}$ Vários outros haviam sido organizados em Mamanguape, tais como o "Cine Nostalgia".

${ }^{52}$ Em alguns momentos Muniz foi à parte superior do cinema (antiga cabine de projeção) para fazer tomadas trabalhando com o zoom, estas tentativas foram pensadas in loco para a montagem final.
} 
as músicas capturadas durante a Semana da Saudade, as quais compuseram a parte sonora do vídeo. Tínhamos então o desafio de concluir o TCC juntamente com a análise das imagens e a montagem do vídeo, que foi finalizado para a banca de defesa.

\section{LIMITES DO COMPARTILHAMENTO PELA INTERNET: DESDOBRAMENTOS E NOVOS DESAFIOS}

Após a finalização do vídeo Imagens e memórias: o cinema no vale do Mamanguape, fizemos a entrega de DVD's aos personagens ${ }^{53}$ envolvidos introduzindo um termo de cessão de uso de imagem para os respectivos personagens assinarem e permitirem, formalmente, o uso de suas imagens no filme e sua divulgação para fins acadêmicos, não comerciais.

Por fim o disponibilizamos no canal de YouTube de José Muniz Neto, acompanhado por Júnior da Locadora que nos solicitou no sentido de adicionar o vídeo também em seu canal eletrônico de vídeos Recorda Mamanguape ${ }^{54}$. Ele também colocou uma marca d'água no vídeo para sinalizar o pertencimento ao seu canal e no espaço de descrição do filme fez questão de ressaltar sua identidade pessoal com os cinemas do Vale e sua descendência dos irmãos David.

Ainda em 2016, com base no trabalho de pesquisa realizado, José Muniz Neto submeteu um argumento para documentário num Edital paraibano de formação em roteiro de cinema. Foi selecionado junto a outros jovens cineastas para participar de quatro dias de imersão para produção de roteiros na cidade de Congo - PB, no VI JABRE ${ }^{55}$. Um ano depois, nosso vídeo ${ }^{56}$ Imagens e memórias: o cinema no Vale do Mamanguape foi selecionado para a Mostra SESC Cinema da Paraíba ${ }^{57}$ junto com outros 19 filmes paraibanos.

Júnior postou então a notícia da seleção do vídeo em sua página eletrônica ${ }^{58}$ e foi parabenizado pelos muitos frequentadores daquele sítio. Neste seu comentário, percebe-se

\footnotetext{
${ }^{53}$ Ao todo foram dez personagens, no entanto, não reencontrei uma personagem.

${ }^{54}$ Disponivel em: <https://www.youtube.com/channel/UC 8vLwtcwu-x-mtR8obgZ3w>. Acesso em: junho de 2017.
}

55 O JABRE é um Laboratório para Jovens Roteiristas do Interior da Paraíba, projeto coordenado por Virgínia Silva e Torquato Joel, "[...] oferecendo anualmente aos jovens interioranos selecionados uma experiência de imersão coletiva por 4 dias numa pousada da cidade do Congo, no Cariri Paraibano, para que transformem o argumento com o qual se inscreveram no Laboratório em um roteiro cinematográfico, pronto para disputar editais e ser apresentado a produtoras" (SILVA, 2015, p. 3).

${ }^{56} \mathrm{O}$ mesmo que integra o TCC.

${ }^{57}$ De 04 a 07 de Julho de 2017, no Sesc Cabo Branco na cidade de João Pessoa - PB.

58 Transcrevemos (postado em 17jun2017): "Tenho q registrar esse acontecimento e agradecer ao antropólogo José Muniz pelo trabalho, onde, durante uma semana, me acompanhou em um evento muito importante para mim e para a população da cidade de Rio tinto a "mostra de filmes antigos"que realizei em 2016. Um resgate da história do antigo cine Orion. Foi muito emocionante! 
que a seleção do filme na Mostra SESC lhe causou entusiasmo e satisfação, já que permitiaIhe evocar seu evento bem como a importância do trabalho da família David com o cinema na região do Vale e em especial junto à população de Rio Tinto. Diante dessas reações nos perguntamos até que ponto a dimensão etnográfica e antropológica contida no vídeo podia ser por ele percebida.

Estávamos no limite com a noção de "compartilhamento". Em que medida esse tipo de apropriação na internet leva a ocultar outras ambiências ou personagens que aparecem e são entrevistados no filme? Portanto, como restituir e agregar mais amplamente nossas memórias coletivas em sua dimensão propriamente antropológica? Como questionar criticamente as relações de poder que tendem a ser constantemente reificadas, dependendo do modo como imagens e vídeos circulam em sítios e canais eletrônicos? De quem, afinal, são essas histórias? ${ }^{59}$

Como, enfim, interpretar a apropriação do trabalho antropológico a partir dessas diversas experiências? Ficam assim esboçadas nossas indagações para reflexões acerca das memórias coletivas, seu compartilhamento pela internet e as questões éticas implicadas. Esta pesquisa sobre os cinemas será continuada agora no curso de Mestrado em Antropologia da UFPB. No âmbito de nosso grupo de pesquisa AVAEDOC seguimos refletindo e experimentando formas de organização e de disponibilização de nossos trabalhos em sítios e canais eletrônicos ${ }^{60}$.

\section{REFERÊNCIAS}

BANKS, M. Dados visuais para pesquisa qualitativa. Porto Alegre: Artmed, 2009.

BARBOSA, A.; CUNHA, E. T. Antropologia e Imagem. Rio de Janeiro: Jorge Zahar, 2006.

BENJAMIM, Walter. Obras escolhidas: magia e técnica, arte e política. $3^{a}$ edição. São Paulo: Brasiliense, 1987.

CALVET, Louis-Jean. Tradição oral \& tradição escrita. São Paulo: Parábola, 2011.

CANEVACCl, Massimo. Antropologia do cinema: do mito à indústria cultural. São Paulo: Editora brasiliense, 1990.

Parabéns pelo trabalho! Agora é mostrar para o mundo! Agradecendo o apoio de D. Neuzomar De Sousa Silva ASTEC". Este apoio da ASTEC é referente ao evento Semana da Saudade, na mostra de filmes antigos."

${ }^{59}$ Referência à expressão usada num artigo de David MacDougall (1997).

${ }^{60}$ Tais como o canal "avaedoc on vimeo", disponível em: <https://vimeo.com/user15354817>. Acesso em: julho de 2017. 
COMOLLI, Annie. Elementos de método em antropologia fílmica. In: FREIRE, Marcius; LOURDOU, Philippe (Orgs.). Descrever o visível: cinema documentário e antropologia fílmica. São Paulo: Estação Liberdade, 2009, p. 23-52.

ECKERT, Cornelia.; ROCHA, Ana Luiza. Antropologia visual em suas aprendizagens: pesquisa, ensino e questões éticas. Revista Iluminuras, n. 5, v. 1, 2004. Disponível em: < >. Acesso em: 10 mai. 2012.

Imagem recolocada: pensar a imagem como instrumento de pesquisa e análise do pensamento coletivo. Revista Iluminuras, Porto Alegre: UFRGS, v. 2, n. 3, 2001. Disponível em: < http://seer.ufrgs.br/iluminuras/issue/view/768>. Acesso em: 23 abr. 2009.

A preeminência da imagem e do imaginário nos jogos da memória coletiva em coleções etnográficas. Brasília: ABA, 2015.

FRANCE, Claudine de. Cinema e Antropologia. Campinas, Unicamp. 1998.

GONÇALVES, Marco Antonio. Etnobiografia: biografia e etnografia ou como se encontram pessoas e personagens. In: GONÇALVES, Marco Antonio; MARQUES, Roberto; CARDOSO, Vânia Z. (Orgs.). Etnobiografia: subjetivação e etnografia. Rio de Janeiro: 7Letras, 2012, p. 19-42.

HALBWACHS, Maurice. A memória coletiva nos músicos. In: _. A memória coletiva. São Paulo: Edições Vértice, 1990, p. 161-189.

LISBOA, Caio Nobre. Ofício e performance do músico no desfile cívico de sete de setembro em Rio Tinto: aproximações antropológicas. 2016. 80f. Trabalho de Conclusão de Curso (Bacharelado em Antropologia, Habilitação em Antropologia Visual) Universidade Federal da Paraíba, Rio Tinto, 2016. [Orientador: Prof. Dr. João Martinho Braga de Mendonça].

MARIE, Michel. A obra de Pierre Perrault na história do cinema: singularidade e herança. In: ARAÚJO, Juliana; MARIE, Michel (Orgs). Pierre Perrault: o real e a palavra. Belo Horizonte: Balafon, 2012, p. 1324.

MACDOUGALL, David. De quem é essa história?. Cadernos de Antropologia e Imagem, v. 2, n. 5, Rio de Janeiro: UERJ, p. 93-105, 1997.

MENDONÇA, João Martinho de. Entre fotografias antigas e redes sociais: trajetórias de pesquisa fotográfica no interior de Minas Gerais e da Paraíba. Iluminuras, Porto Alegre, v.12, n. 28, p. 70-102, jul./dez. 2011.

NOVAES, Sylvia Caiuby. Imagem e ciências sociais: trajetória de uma relação difícil. In: BARBOSA, Andréa; CUNHA, Edgar Teodoro da; HIKIJI, Rose Satiko G. (Orgs). Imagem-conhecimento: antropologia, cinema e outros diálogos. Campinas: Papirus, 2009, p. 35-59.

PANET, Amélia et al. Rio Tinto: estrutura urbana, trabalho e cotidiano. João Pessoa: UNIPÊ, 2002.

PERRAULT, Pierre. 0 objetivo documentário. In: ARAÚJ0, Juliana; MARIE, Michel (Orgs). Pierre Perrault: 0 real e a palavra. Belo Horizonte: Balafon, 2012, p. 41-56.

POLLAK, Michael. Memória, esquecimento, silêncio. Estudos Históricos, Rio de Janeiro, v. 2, n. 3, p. 3$15,1989$. 
POLLAK, Michel. Memória e identidade social. Estudos Históricos, Rio de Janeiro, v. 5, n. 10, p. 200212, 1992.

PRELORÁN, Jorge. Conceitos étnicos e estéticos no cinema etnográfico. In: Caderno de Textos de Antropologia Visual. Rio de Janeiro: Museu do índio, 1987, p. 8-20.

QUEIROZ, Maria Isaura Pereira de. Relatos orais: do "indizível" ao "dizível". In: SIMSON, 0. M. von (Org.). Experimentos com histórias de vida (Itália-Brasil). São Paulo: Vértice, 1988, pp. 14-43.

SAMAIN, Etienne; MENDONÇA, João M.. Entre a escrita e a imagem. Diálogos com Roberto Cardoso de Oliveira. Revista de Antropologia, São Paulo, USP, 2000, v. 43, n¹, p. 185-236.

SCHAFER, Murray. 0 ouvido pensante. São Paulo: Fundação Editora da UNESP, 1991.

SEGATA, Jean; RIFIOTIS, Theofilos (orgs.). Políticas etnográficas no campo da cibercultura. Brasília: ABA, 2016.

SILVA, Adelina Maria Pereira da; JUSTIÇA, Paula. A comunicação mediada por computador no ciberespaço: uma perspectiva antropológica. In: RIBEIRO, José da Silva; BAIRON Sérgio (Orgs.). Antropologia Visual e Hipermedia. São Paulo: Edições Afrontamentos, 2005.

Ciberantropologia: 0 estudo das comunidades virtuais. In: RIBEIRO, José da Silva; BAIRON Sérgio (Orgs.). Antropologia Visual e Hipermedia. São Paulo: Edições Afrontamentos, 2005.

SILVA, Mateus Araújo. Com a palavra, Perrault. In: ARAÚJ0, Juliana; MARIE, Michel (Orgs.). Pierre Perrault: o real e a palavra. Belo Horizonte: Balafon, 2012, p. 101-105.

SILVA, Virgínia de Oliveira. Educação e Cinema: A "partilha do sensível" no cinema contemporâneo e interiorano. In: SEMINÁRIO BRASILEIRO DE ESTUDOS CULTURAIS E EDUCAÇÃO, 6. - SEMINÁRIO INTERNACIONAL DE ESTUDOS CULTURAIS E EDUCAÇÃO, 3., 2015, Canoas. Anais eletrônicos. Canoas: ULBRA, 2015.2 Disponivel em: <http://www.sbece.com.br/2015/resources/anais/3/1430021749 ARQUIVO VIRGINIA SILVA ARTIGO RS Canoas 06.2015.pdf>. Acesso em: julho de. 2017.

STAM, Robert. Bakhtin: da teoria literária à cultura de massa. São Paulo: Editora Ática, 1992. 